\title{
INCIDENTAL CAPTURE OF A SPINNER DOLPHIN, STENELLA LONGIROSTRIS (GRAY, 1828), IN A SHARK GILLNET OFF SOUTHEASTERN BRAZIL
}

\author{
Marcos César de Oliveira Santos, ${ }^{2 *}$ and Eduardo Humberto DitT ${ }^{3}$
}

Incidental captures in fishing operations have been reported in Brazilian waters for at least 22 cetacean species: Pontoporia blainvillei, Sotalia guianensis, S. fluviatilis, Tursiops truncatus, Steno bredanensis, Stenella frontalis, S. coeruleoalba, S. longirostris, S. clymene, Delphinus sp., Pseudorca crassidens, Grampus griseus, Globicephala melas, G. macrorhynchus, Orcinus orca, Inia geoffrensis, Hyperoodon planifrons, Kogia sima, Physeter macrocephalus, Balaenoptera acutorostrata, Megaptera novaeangliae and Eubalaena australis (e.g. Pinedo, 1994; Siciliano, 1994; Zerbini and Kotas, 1998; Ott et al., 2002; Moreno et al., 2005). The most common species incidentally caught are the Guiana dolphin (S. guianensis), and the franciscana (P. blainvillei) (Siciliano, 1994). This evidence suggests that most cetacean species occurring in Brazilian waters are involved in fishing operations, but some of these interactions are still unreported. The present note describes the incidental capture of at least one spinner dolphin (Stenella longirostris) in a gillnet set for sharks off the Brazilian southeast coast.

In January 1993, one of the authors (EHD) left Ubatuba $\left(22^{\circ} 53^{\prime} S, 45^{\circ} 08^{\prime} \mathrm{W}\right)$, São Paulo state, onboard a gillnet fishing boat in order to investigate incidental captures of marine turtles. The final destination was the waters off Cabo Frio $\left(23^{\circ} 00^{\prime} \mathrm{S}, 42^{\circ} 01^{\prime} \mathrm{W}\right)$, Rio de Janeiro state. The $14 \mathrm{~m}$ long boat had a 3ton load capacity and 10-12 days of autonomy. Its $12 \mathrm{~m}$ high by $3900 \mathrm{~m}$ long gillnet stayed around $12 \mathrm{~h}$ a day in the water, from sunset to sunrise, in 10 fishing days. The net had a mesh of $24 \mathrm{~cm}$ between opposite knots. During the trip, the main target species were: hammerhead sharks (Sphyrna lewini), mackerel sharks (Isurus oxyrinchus), carchariniid sharks (Carcharinidae), manta rays (Myliobatidae), sailfishes (Istiophorus platypterus) and mackerels (Auxis thazard).

On 21 January 1993, three dolphins were incidentally captured. They were dead when the net was hauled onboard. Their fins were cut off to release them from the net and they were discharged to the sea. Through the analysis of the single photograph available (Figure 1), the captured dolphin was later identified as a spinner dolphin (S. longirostris). The main diagnostic characteristics were the relatively long, narrow and dorso-ventrally flattened rostrum; the tripartite color pattern consisting of a dark grey dorsal cape, a lighter lateral field and light grey ventral field; and a dark stripe passing from the eye forward close to the apex of the melon (see Perrin, 1998). The photographed dolphin measured $c a .190 \mathrm{~cm}$ in total length, which fits in the range of an adult S. longirostris (see Perrin and Gilpatrick, 1994). The capture occurred in waters deeper than $480 \mathrm{~m}$, which was the limit of the boat's depth sounder. As no positioning system was available, the exact location where the dolphins were captured is unknown. However, with the help of a nautical chart (DHN 1804) and the information gathered on the trip, the capture was estimated to have occurred around $90 \mathrm{~km}$ from the coast in waters with depths ranging between 600 and $1000 \mathrm{~m}$. Based on the fact that the three dolphins were captured in the same fishing set, and considering the highly gregarious behavior of $S$. longirostris (Leatherwood and Reeves, 1983; Perrin, 1998), the two other dolphins might also have been spinner dolphins. However, associations of spinner dolphins with Atlantic spotted dolphins ( $S$. frontalis) and pantropical spotted dolphins (S. attenuata) have been observed in neighboring waters (Daniel et al., 19925; Zerbini et al., 2004; Siciliano et al., 2006). Thus, no conclusions on the two other captured individuals can be reached. This is the first account of incidental capture of spinner dolphin in a shark gillnet in Brazilian waters. Two years later, another incidental capture of the same species was reported in southern Brazil (30 5$)$, which represented the southernmost record in the South West Atlantic Ocean (see Kotas and Zerbini, 1998).

Except for the Fernando de Noronha Archipelago $\left(03^{\circ} 50^{\prime} \mathrm{S}\right)$, where a local population has been the focus of a longitudinal study since the 1990s (e.g. Silva Jr. et al., 2005; 2007), spinner dolphins remain poorly known along its range in the Southwest Atlantic, where it can be found both on the continental shelf as well as beyond the slope (Secchi and Siciliano, 1995; Zerbini et al., 2004; Moreno et al., 2005; Siciliano et al., 2006). Several sightings have been reported in the area between Ubatuba and Cabo Frio (Daniel et al., 1992; Zerbini et al., 2004). This area is strongly influenced by a seasonal upwelling, which turns local coastal and deeper waters into a highly productive zone for fishing purposes, including efforts directed towards sharks in deeper waters (Borzone et al., 1999).

\footnotetext{
${ }^{1}$ Received on 5 May 2008. Accepted on 4 May 2009. Managed by Nélio Barros / David Aurioles.

2 Projeto Atlantis, Laboratório de Biologia da Conservação de Cetáceos, Departamento de Zoologia, Instituto de Biociências da Universidade Estadual Paulista 'Júlio de Mesquita Filho' (UNESP), Campus Rio Claro, Avenida 24-A, 1.515, Bela Vista, Rio Claro, SP, Brazil, 13506-900.

* Corresponding author, e-mail: sotalia@gmail.com.

${ }^{3}$ IPÊ - Instituto de Pesquisas Ecológicas, Caixa Postal, 47, Nazaré Paulista, SP, Brazil, 12960-000. E-mail: eduditt@ipe.org.br.

${ }^{4}$ Diretoria de Hidrografia e Navegação, DHN, 180. Marinha do Brasil, 1985.

${ }^{5}$ Daniel, M. C., Fioretti, M. M. and Rocha, A. R. (1992) Ocorrência de Stenella longirostris (Cetacea, Delphinidae) na região de Ubatuba, litoral norte do Estado de São Paulo. Pages 20-22 in Anales, 3a Reunión de Trabajo de Especialistas en Mamíferos Acuáticos de América del Sur, 25-30 July 1988, Montevideo, Uruguay.
} 


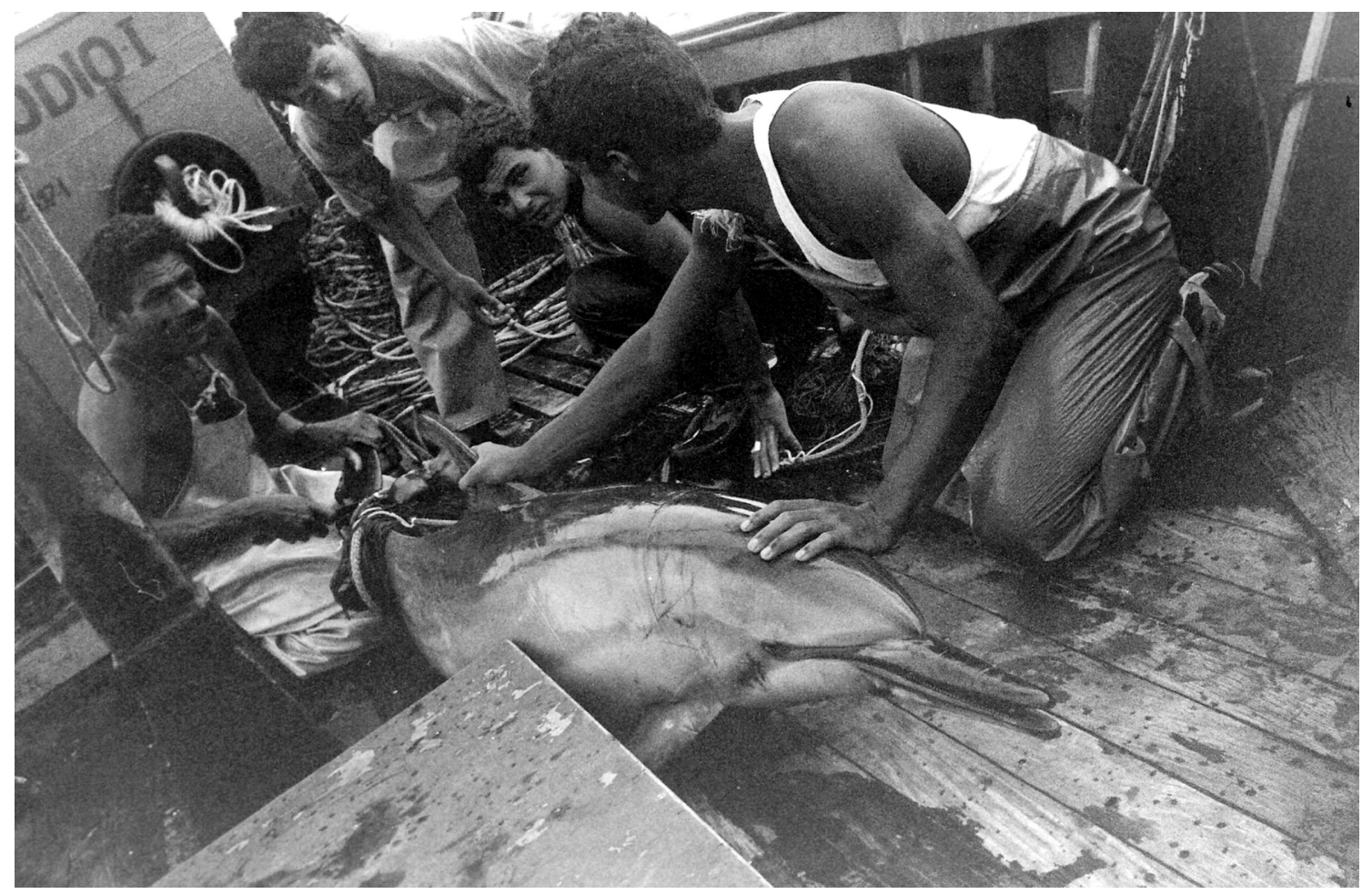

Figure 1. Adult spinner dolphin (Stenella longirostris) incidentally captured in a gillnet set for sharks in southeastern Brazil.

The rising importance of fisheries in the country's economy may explain an increase in fishing effort over the last 15 years (see Pimenta et al., 19936; Tiago et al., 1995; Zerbini and Kotas, 1995; Ávila da Silva et al., 2007). The gregariousness of S. longirostris and the increasing gillnet fishing in southeastern Brazil justify a closer monitoring of this fishery, which has a high potential for bycatch.

\section{Acknowledgements}

We are indebted to Berenice M. G. Gallo and Luciana S. Brondizio from Projeto TAMAR-IBAMA who allowed the use of their data; to Alexandre N. Zerbini, Eduardo R. Secchi, and Salvatore Siciliano who critically reviewed the first drafts of this note; to Alberto F. Amorim and Carlos A. Arfelli (Instituto de Pesca, Santos) who identified captured fish species; and to Nélio B. Barros who made important critiques to our poster presentation at the $6^{\text {th }}$ South American Meeting of Marine Mammal Specialists held in Florianópolis, Brazil, in 1994. MCOS receives a fellowship from Fundação de Amparo à Pesquisa do Estado de São Paulo (FAPESP), process \#05-59439-5. We thank Alexandre N. Zerbini and an anonymous reviewer for suggestions to improve this note.

\section{References}

Ávila da Silva, A.O., Carneiro, M.H., Mendonça, J.T., Servo, G.J. De M., Bastos, G.C.C. And Batista, P. De A. (2007) Produção pesqueira marinha do Estado de São Paulo no ano de 2005. Série Relatórios Técnicos do Instituto de Pesca do Estado de São Paulo, São Paulo, 26: 1-44. [Available from: http:// www.pesca.sp.gov.br/publicacoes/php].

Borzone, C.A., Pezzuto, P.R. And Marone, E. (1999) Oceanographic characteristics of a multi-specific fishing ground of the Central South Brazil Bight. Marine Ecology 20: 131-146.

Leatherwood, S. AND ReEves, R.R. (Eds) (1983) The Sierra Club Handbook of Whales and Dolphins. Sierra Club Books, San Francisco, CA. 302pp.

Moreno, I.B., Zerbini, A.N., Danilewicz, D., Santos, M.C. DE O., Simões-Lopes, P.C., Laílson-Brito Jr., J. And Azevedo, A.F. (2005) Distribution and habitat characteristics of dolphins of the genus Stenella (Cetacea: Delphinidae) in the southwest Atlantic. Marine Ecology Progress Series 300: 229-240.

OtT, P.H., SeCChI, E.R., MoReno, I.B., Danilewicz, D., CRESPO, E.A., Bordino, P., Ramos, R.M.A., Di Beneditto, A.P.M., Bertozzi, C., Bastida, R., Zanelatto, R.C., Perez, J. and Kinas, P.G. (2002) Report of the working group on fishery interaction. The Latin American Journal of Aquatic Mammals 1 (special issue 1): 55-64.

Perrin, W.F. (2001) Stenella longirostris. Mammalian Species 599: $1-8$

\footnotetext{
${ }^{6}$ Pimenta, E.G., Amorim, A.F. and Arfelli, C.A. (1993) Captura de cações e raias na região de Cabo Frio - RJ (março/92). Page 5 in Resumos,
} VI Reunião do Grupo de Trabalho sobre Pesca e Pesquisa de Tubarões e Raias do Brasil, 11-16 July 1993, Pernambuco, Brazil. 
Perrin, W.F. and Gilpatrick JR, J.W. (1994) Spinner dolphin Stenella longirostris (Gray, 1828). Pages 99-128 in S.H. RIDGWAY AND R. HARRISON (Eds) Handbook of Marine Mammals: The First Book of Dolphins. Academic Press, London. v.5. 416pp.

Pinedo, M.C. (1994) Review of small cetacean fishery interactions in Southern Brazil with special reference to the franciscana, Pontoporia blainvillei. Reports of the International Whaling Commission 15 (special issue): 251-259.

SECCHI, E.R. ANd SicILIANO, S. (1995) Comments on the southern range of the spinner dolphin (Stenella longirostris) in the western South Atlantic. Aquatic Mammals 21: 105-108.

Siciliano, S. (1994) Review of small cetaceans and fishery interactions in coastal waters of Brazil. Reports of the International Whaling Commission 15 (special issue): 241-250.

Siciliano, S., Moreno, I.B., Demari e Silva, E. and Alves, V.C. (2006) Baleias, botos e golfinhos na Bacia de Campos. Série Guias de Campo: Fauna Marinha da Bacia de Campos. Escola Nacional de Saúde Pública, Fundação Oswaldo Cruz, Rio de Janeiro, RJ, Brasil. 100pp.

Silva JR., J.M., SiLVA, F.J.L. AND SAZIMA, I. (2005) Rest, nurture, sex, release, and play: diurnal underwater behaviour of the spinner dolphin at Fernando de Noronha Archipelago, SW Atlantic. Journal of Ichthyology and Aquatic Biology 9(4): 161-176.

Silva JR., J.M., Silva, F.J.L., SAzIMA, C., ANd Sazima, I. (2007) Trophic relationships of the spinner dolphin at Fernando de Noronha Archipelago, SW Atlantic. Scientia Marina 71: 505-511.

Tiago, G.C., TutuI, L.S. dos S., von SeckendorfF, R.W., Grassi, R.T.B. AND INÁCIO, M.L. DA S. (1995) Análise da frota pesqueira sediada em Ubatuba, Estado de São Paulo, Brasil. Boletim do Instituto de Pesca 22(2): 71-83.

ZerbinI, A.N. AND Kotas, J.E. (1998) A note on cetacean bycatch in pelagic driftnetting off southern Brazil. Reports of the International Whaling Commission 48: 519-524.

Zerbini, A.N., Secchi, E.R., Bassoi, M., Dalla Rosa, L., Higa, A., SousA, L., Moreno, I.B., Moller, L.M. And CAON, G. (2004) Distribuição e abundância relativa de cetáceos na Zona Econômica Exclusiva da região sudeste-sul do Brasil. Série Documentos REVIZEE: Score Sul. Instituto Oceanográfico da Universidade de São Paulo, São Paulo, Brasil. 40pp. 